\title{
Class struggle in the era of post-politics
}

\section{Representing the Swedish port conflict in the news media}

\author{
Ernesto Abalo \& Diana Jacobsson \\ Department of Languages and Communication, Jönköping University, Sweden
}

\begin{abstract}
This article addresses how class as a category of conflict and struggle is understood and shaped discursively in mainstream media today. We utilise a case study of how Swedish news media represents the long-lasting conflict in the Swedish labour market between the Swedish Dockworkers' Union and the employer organisation, Sweden's Ports. Using critical discourse analysis, we show two ways in which class relations are recontextualised in three Swedish newspapers. One is through obscuring class and centring the conflict around business and nationalist discourses, which in the end legitimise a corporate perspective. The other, more marginalised, way is through the critique of class relations that appears in subjective discourse types. This handling of class, we argue, serves the reproduction of a post-political condition.
\end{abstract}

Keywords: class, critical discourse analysis, hegemony, media, strike

\section{Introduction}

In this article, we aim to examine how class as a category of conflict and struggle is understood and shaped discursively in mainstream media today. We do this by studying the case of the Swedish news media's representation of the long-lasting conflict in the Swedish labour market between the Swedish Dockworkers' Union [Svenska Hamnarbetarförbundet] and the employer's organisation, Sweden's Ports [Sveriges Hamnar]. Departing from critical theory, we view exploitation as the core of the social relationship between capital and labour and argue that the structure of class is defined by conflicts of interest (Marx, 1996; Wright, 2005). Using critical discourse analysis as a method, we analyse how the named labour market conflict is constructed via editorial and journalistic choices.

Studying the news media's representation of class relations is central to understanding how the media reinforces or challenges reigning neoliberal politics and the post-political condition that has characterised Western democracy under neoliberal rule. We argue that today's societies are largely defined by neoliberal politics and the ideals of market logic, implemented on a large scale in the form of increased deregulation and privatisation (Harvey, 2010). Neoliberal capitalism has widened the gaps between the capitalist class and the working class in terms of economic inequality

Abalo, E., \& Jacobsson, D. (2021). Class struggle in the era of post-politics: Representing the Swedish port conflict in the news media. Nordicom Review, 42(S3), 20-34. https://doi.org/10.2478/ nor-2021-0024 
(Therborn, 2018). This is also the case in Sweden, a country that historically has had a strong labour movement and low levels of inequality, where the distance between rich and poor is rising faster than in any other OECD country (OECD, 2017). In the labour market specifically, neoliberalism has brought a change in labour relations and has weakened unions, with the power balance between labour and capital shifting to an increased advantage for the employer (Lindberg \& Neergard, 2013; Rehmann, 2013). This has been identified as a development (in Sweden and internationally) where the workers' power to influence their working conditions is fading (Allvin \& Sverke, 2000; Furåker, 2005; Kjellberg, 2011). It has been noted that the implementation of neoliberal politics with an increase in insecure employment and decreased workers' power is a rather silent process that does not involve thorough debate (Bengtsson, 2008; Grönlund, 2004). The acceptance of neoliberal capitalism as common sense among those in the political mainstream in the West, a general positioning towards the political centre, and the lack of thorough ideological debate are what scholars have characterised as a post-political condition (Mouffe, 2005).

The above indicates changed power relations between actors in the labour market in a neoliberal and post-political context. In this article, we address these issues and discuss how the union's and business representatives' sides are represented in media discourse and how the way problems are defined in the port conflict can be understood from a class perspective.

Previous research about the representation of class in the media, especially that of (reality) television, has focused on questions of voice and morality and exposed some sort of middle-class gaze characterising class representations, leading to the underrepresentation of the working class and the construction of the working class as morally problematic (Bennett, 2013; Eriksson, 2015; Jakobsson \& Stiernstedt, 2018a, 2018b; Lawler, 2005; Lyle, 2008; Skeggs, 2004; Skeggs \& Wood, 2011; Stiernstedt \& Jakobsson, 2019). Studies focusing on international journalism (Abalo, 2017; Lugo-Ocando, 2015) have highlighted how the objectivistic nature of journalism serves to reify class relations and accept the politics behind inequality.

Closer to this study, analyses of the representation of class and labour relations in news journalism identify a more subtle form of weakening the power of the working class. The seminal work by the Glasgow Media Group $(1976,1980)$ shows how the British news coverage of the coal miners' strike in the 1980s promotes society's dominant ideology, where workers' voices are backgrounded and considered less important than management voices. A more recent study (Hart, 2017) shows that the same strike is framed as a war - a type of framing used to push an anti-trade-union agenda in the media. Kumar (2007), in a study of the coverage of the UPS strike in American corporate media, shows how class conflict to some extent is neutralised by the use of a nationalist perspective, where the interests of the capitalists are perceived as the interests of the nation. Research has also found the mainstream media to conceal corporations' responsibility when reporting on poor working conditions in the Global South (Cotal San Martin, 2019). Scholars have also noted a decline in the labour beat (Martin, 2007; Nerone 2009) In the Swedish context, studies of news journalism during a labour-market crisis point to how the working class is dismantled as a collective due to the journalistic focus on individualised problem descriptions (Jacobsson \& Ekström, 2016) and the way the main journalistic story is centred around the business elite and market logic (Jacobsson, 2018). 
It has been argued that workers in today's capitalist society are rarely a class for themselves (in terms of class consciousness or collective organisation to change their conditions), as the neoliberal neglect of structural inequalities does not acknowledge class as an important category (Harvey, 2010; Lawler, 2005; Savage et al., 2001). The study of discourses in conjunction with conflicts in the labour market is therefore particularly important, as these events represent critical situations where the power balance between labour and capital inevitably becomes visible. With this study, we contribute to the understanding of class and the media by focusing on class as a relation of struggle and conflict in capitalism, which lets us scrutinise how the media recontextualises that sort of antagonism, and how such representations, in the end, serve to challenge or reinforce class rule.

The next section presents our theoretical framework. We then present our methods and materials. Subsequently, the results of the study are presented, followed by the study's conclusions.

\section{Theoretical framework}

We understand the representation of class in the media as situated in a larger context of political power struggles in society, especially the reinforcement and contestation of capitalist hegemony. Before discussing the media's role in such struggles, we begin by outlining our understanding of class, class struggle, and class interests.

Class is here understood from a Marxist perspective, emphasising the power relations between different groups in a specific locus of capitalist production. The emphasis on relations and structure in this approach makes "class" an adjective rather than a noun (Wright, 2005). Thus, rather than exploring specific clusters, groups, or individuals as a class - which is commonly done in sociology - this perspective lets us analyse the class character of specific relations, involving groups and individuals. Central to this understanding of class is the concept of exploitation, which considers, in a class relationship, the material deprivation of one group relative to another, where the exploited is excluded from specific production resources and the exploiter is provided material advantages (Wright, 2005). In capitalism, exploitation is tied to the capitalist's subtraction of surplus value from the worker's labour, which provides the former with material advantages over the latter. This uneven power relationship puts conflict at the core of class relations, making class interests and class struggle pivotal for the understanding of class agency (Wright, 2005). Class interests constitute "the material interests of people derived from their location-within-class-relations" and explain the actions of groups and individuals in relation to class (Wright, 2005: 21). The capitalist and the worker have opposing class interests because, in general, what enhances the power of one group restricts the power of the other. This takes us to class struggle, which is the "conflicts between the practices of individuals and collectivities in pursuit of opposing class interests" (Wright, 2005: 21). As Wright (2005) notes, the forms of class struggle can vary from strategies undertaken by individual workers to reduce the workload, to the organised struggle between worker and capitalist collectivities.

This understanding of class helps us conceptualise the analysed port conflict as an articulation of class struggle, where the opposed class interests of the dockworkers and the employer's organisation are expressed through the conflict at hand. This does 
not mean that other conceptualisations of class are not useful for understanding the complex character of class, or that gender or ethnicity are not important as relations of domination; however, the conceptualisation outlined above puts the focus on the antagonism inherent in class relationships such as the one between the dockworkers and their employers. By centring on class as a relationship of conflict, it is then possible to understand how the news media, by reporting on the port strike, also represent questions of class.

The relationship between class and the news media is multifaceted, and it is here approached through the concept of hegemony, which in brief means the rule of a social group by consent and under moral and intellectual leadership (Gramsci, 1971). At the core of this leadership is ideology, or the worldviews that are disseminated and established in such arenas as the political system, the school system, and the media. Hegemony is always challenged and in motion, and in order to achieve consent, the ruling social groups must compromise without compromising the core of hegemony - the material basis of the leadership itself. In capitalism, this core is class rule and the mode of production that makes class relations inevitable.

The news media's role in building hegemony has partly to do with being, for the most part, profit-oriented enterprises that are sites of class relations themselves. Market logics have led to ownership concentration and the naturalisation of a corporate business model (Herman \& McChesney, 1997), to an increased rationalisation in newsrooms (Davis, 2010; Freedman, 2010), and to fostering elite-centred and state-protecting perspectives (Herman \& Chomsky, 2002). Moreover, understanding the production process, which is heavily routinised (Tuchman, 1978), is key. Allan (1999) argues that journalism takes a bureaucratic understanding of society for granted, which leads to a hierarchy of credibility, where actors at society's top are more likely to become sources in the media. Such sources become what Hall and colleagues (1978) call primary definers and are given the power to establish the problem to be addressed, at the same time as they delimit the perspectives that fit the story. Furthermore, Hallin (1989) points to the relationship between the values in newsrooms and the dominant values in society. Things that are generally perceived as consensual in society will face little or no debate in the media, whereas what are considered legitimate controversies are treated as objectively and neutrally as possible. Hallin's reasoning helps explain the limits of debate in the news media and implies that norms and dominant perspectives in society serve to constrain media production and limit the manoeuvring space for media actors. In the context of a seemingly economically and ideologically unchallenged capitalism, editorial choices can, in this sense, serve the reproduction of market-friendly and class-dominant perspectives by adhering to norms and dominant values in society. However, this is not to say that the media are free from critique. The hegemonic workings of the media are to integrate deviant perspectives, which, however, are absorbed by the dominant view (Allan, 1998; Gitlin, 2003). Media research on the representation of class issues has shown that a nationalist framework in the media can absorb class-related problems by pointing to national well-being, which is made to cohere with the interests of the elite (Kumar, 2007; Salter \& Weltman, 2011). In this way, the media can take a "neutral" stance, include critical voices, and in the end, promote the status quo. 


\section{Case, material, and method}

Case

The conflict between the Swedish Dockworkers' Union and Sweden's Ports has roots in the 1970s, when the Dockworkers' Union broke away from the Transport Workers' Union (Transport), which in turn is part of the Swedish Trade Union Confederation (LO). Since then, the Dockworkers' Union has lacked a collective bargaining deal, which instead has been signed by the employers and the LO-affiliated union, despite the Dockworkers' Union being the biggest union in some of the ports. The conflict at hand has therefore been about the rights to sign a bargaining deal and to take part in local negotiations, rather than being about salaries.

The analysed conflict erupted in 2017 in the port of Gothenburg, which, since 2012, has been run by Maersk-owned APM Terminals. According to the Dockworkers' Union, in April 2018, the port management did not recognise the union as the workers' representatives, because the bargaining agreement had been signed with Transport. Among other things, this denied the Dockworkers' Union the right to have their own safety officials and to be part of local negotiations (Hamnarbetarförbundet, 2019). This escalated the conflict, which then led to lockouts called for by the employers, as well as national point strikes called for by the Dockworkers' Union. After several months of conflict, a second-hand bargaining agreement was signed by the Dockworkers' Union and Sweden's Ports.

The conflict was also used as an argument for restricting the strike law in Sweden, with the industry claiming it to be unreasonable for workers to be allowed to strike if the workplace already has a bargaining agreement with a union. In June 2019, a restricted strike law - drafted by LO, the white-collar confederation Tjänstemännens Centralorganisation (TCO), and the Confederation of Swedish Enterprise - was passed (Bengtsson, 2019).

\section{Material}

In this study, we analyse material from the print versions of three Swedish newspapers: Aftonbladet $(A B)$, Dagens Nyheter $(D N)$, and Svenska Dagbladet $(S v D)$. These newspapers were chosen because they have a national reach and represent different ideological positions in their editorial pages: $A B$, a tabloid, is independently social democratic; $D N$, a morning paper, is independently liberal; and $S v D$, a morning paper, is independently conservative. With this sample of newspapers, it is possible to cover central news media in the Swedish media landscape as well as different editorial positions, which could be important in relation to the construction of class.

The studied material covers the period between 1 January 2017 and 30 November 2019, making it possible to follow the different stages of the conflict. The material was retrieved through the database Retriever Mediearkivet in December 2019 by searching with the keywords "Hamnarbetarförbundet" [the Dockworkers' Union] and "Sveriges hamnar" [Sweden's ports]. With these keywords, it was possible to retrieve material that mentions any of the key actors in the conflict. In total, 91 items were analysed (see Table 1). Items exclusively addressing online-only articles were excluded, as were the web articles these blurbs referred to. 
Table 1 Overview of the material

\begin{tabular}{lcccc}
\hline Material type & AB & DN & SvD & Total \\
\hline News, general & 2 & 1 & 2 & 5 \\
Economy news & 0 & 31 & 23 & 54 \\
Editorials & 4 & 1 & 3 & 9 \\
Debate & 3 & 3 & 8 & 14 \\
Cultural columns & 5 & 1 & 0 & 6 \\
Blurbs & 0 & 0 & 4 & 4 \\
\hline Total & 14 & 37 & 40 & 91 \\
\hline
\end{tabular}

Comments: Aftonbladet $(A B)$ is an independently social democratic tabloid; Dagens Nyheter (DN) is an independently liberal morning paper; Svenska Dagbladet $(S v D)$, finally, is an independently conservative morning paper.

\section{Method}

Critical discourse analysis (CDA) is utlised to identify the assumptions and ideas that underpin the media discourses. This choice is based on CDA's being a form of discourse analysis with a specific focus on how language use interrelates with power and ideology (see Wodak \& Meyer, 2009). According to CDA, discourse is a form of social practice which is central in the reproduction and transformation of the social status quo. This pairs discourse with ideology. Genre - how a particular social activity is categorised and placed within a language-specific interpretational frame - is of central importance (Fairclough, 1993).

The first step of the analysis was an initial mapping of the content in the news coverage to get an overview of what the story is about and how the conflict is understood. This was followed by a more detailed reading of how the conflict is recontextualised (Machin \& Mayr, 2012) - how meaning is created, what is made salient, and what is obscured. In the more detailed reading, we looked for the following in the discourse:

- Surface elements: article type, section, source, and visual elements (Carvalho, 2008).

- Objects: the broad and narrow topics that are constructed (Carvalho, 2008).

- Salience/suppression: what actors, voices, events, and perspectives are being foregrounded and backgrounded (Machin \& Mayr, 2012).

- Presuppositions: concepts and worldviews that are taken for granted, and underlying assumptions (Machin \& Mayr, 2012).

- Discursive strategies: the ways in which actors shape reality in a certain direction. Two strategies are looked for in the journalistic voice and the quoted actors, respectively: framing strategies (choice of angles), and legitimation (justification of actions) (Carvalho, 2008).

- Lexical choices: what words are used and how they convey different levels of authority (Machin \& Mayr, 2012). 


\section{Results}

There are some differences between the newspapers in terms of genre and discourse types. $A B$ has few news articles, with the lion's share of its published content being opinion pieces (editorials, cultural columns, and debate articles). $D N$ and $S v D$ have a greater proportion of news articles, with much of their news published in the economy section. This categorisation, in terms of genre, is important from a CDA perspective because it sets the framework for how the port conflict and class relations are discursively constructed. Placing the conflict in the economy section is significant because this genre definition encourages certain journalistic angles and perspectives (pro-market reasoning), while subordinating others (the workers' perspective). This leads to a salience and suppression mechanism beyond which voices and opinions are heard, where the market interpretation of the conflict also becomes the legitimised point of departure for discussions of what solutions are reasonable. Furthermore, we find that it is mainly in a few opinion pieces that class positions are expressed more explicitly.

In the following, we present two discursive patterns identified from the analysis of how class relations are constructed, based on how problems, solutions, and responsibilities are constructed; what is presupposed, made salient, and suppressed; and what lexical choices are made. The first, which appears more generally in the materials, concerns the naturalisation of capitalist class interests, where the construction emphasises the port workers' struggle as destructive to the nation. The second, mainly present in the few cultural columns and expressed by individual worker or leftist voices, is the critique against class relations, recontextualised as subjective opinion. These two discursive patterns serve important hegemonic roles: the first by naturalising a hegemonic corporate perspective, and the second by absorbing and neutralising critique.

\section{The common good and the irresponsible others}

One way in which class relations are constructed is by naturalising corporate interests. Through this frame, the conflict becomes a disruptive element within a context characterised by a seeming consensus regarding the priority of market rationales and corporate and national interests. Central here is the construction of the conflict as hurting business and Swedish society rather than business logics being the cause of the conflict.

The context of neoliberal hegemony and the firm establishment of genre - as noted in the decision of the liberal and conservative morning papers to report much of the conflict as economic news - constructs a hierarchical order between the capitalist and labour perspective. In terms of presuppositions, it becomes clear that the imaginable society is one where capitalism goes on without disturbances. Headlines such as "The port conflict a threat to the export giants" (Cederblad, SvD, 19 May 2017), and "Total strike makes the business world hold its breath" (SvD, 5 March 2019) are examples of a recurring theme where the conflict is framed as hurting business. ${ }^{1}$ In the article "Big strike in ports worries the business world" (DN, 4 March 2019) the dockworkers' struggle is interpreted as a threat to society, and corporate interests become synonymous with taking responsibility and keeping clients safe:

The business world is holding its breath and now planning for how to keep production going and clients safe. There is great uncertainty about how the Dock- 
workers' Union's announced strike will hit Swedish businesses. Anna Lööf at Teknikföretagen says the strike will hit society hard.

Sweden is one of the world's most export-dependent nations. There will surely be effects that are dangerous to society. (DN, 4 March 2019)

The lexical choices centred around uncertainty and danger construct an image of working-class interests as damaging to society. This discursive construction of the conflict corresponds to a hegemonic frame within which recurring opinion pieces, as well as journalistic news articles and editorial interpretations of the conflict, are situated.

In line with this, there are examples where pro-business opinions function as the voice of reason, and the market is legitimised, which can be seen in quotations of business actors and in opinion materials by pro-market voices. Moreover, one can find the capitalist class interests being put forward as central to the interests of the nation and the public good, as in a debate article by the economic-political spokesperson of the Liberal Party:

The conflict is accordingly about what a reasonable conflict action is in relation to public interest. To the Swedish export industry, access to the Gothenburg port is crucial for competitive power. (Persson, SvD, 27 January 2017)

The establishment of the port conflict as something threatening business, the nation, and the common good is accompanied by arguments claiming workers' power must be restricted. A common corporate expectation or demand for how to end the conflict is political intervention through legislation. In a debate article in $D N$ (Dahl \& Ärlund, 31 January 2018), signed by two representatives from employer organisations, this demand is implicitly put forward as the only reasonable alternative:

The government has taken responsibility for the serious situation and launched an investigation, with the assignment to revise the right-to-conflict action to protect the collective agreement. But there are critical voices against this. Do those who criticise the investigation not understand what is at stake?

This reasoning implies that those raising pro-worker opinions have not understood the consequences of the conflict, and implicitly, how paving the way for capital is in everyone's best interest. This way of looking at the conflict, where the capitalist interests are made synonymous with the common good, and the dockworkers are identified as the threat, is also echoed in economy news articles. The need for political intervention to protect capitalist class interests is, in different ways, discursively shaped as being synonymous with protecting the industry and Swedish society:

Johan Trouvé, CEO of the West Swedish chamber of commerce thinks it is good the government acts and emphasises how the conflict not only affects Gothenburg but the whole Swedish industry.

"This is a national concern and we are right now on the verge of a situation that is dangerous for society", says Trouvé. (Littorin, DN, 24 May 2017)

Moreover, in the economy news article "'The Dockworkers' Union abuses the conflict weapon"” (Nandorf, DN, 21 January 2018), the vice CEO of the Confederation of Swedish Enterprise is the only actor quoted. He voices distrust of the workers' willingness to end the conflict, by saying that, 
“The Dockworkers' Union is abusing the conflict weapon. They say they use conflict actions to sign a collective agreement, but in reality, they want to affect how APM Terminals organise the work, the forms of compensation upon employment termination, and a lot of strange demands". [...]

"I cannot see the parties solving this situation. A change in the law is needed". (Nandorf, DN, 21 January 2018)

Here, the actions and demands of the Dockworkers' Union are delegitimised in an 'explanation" of what they really are aiming for. That the union wants to have a say in how the employer organises the work is put forward as something odd and part of a hidden agenda, while it could perhaps also be seen as a natural desire for a union.

In the analysed material, voice is given to various business representatives and liberal and conservative voices pushing for a change to the strike law. Analysis reveals how the social democratic minister of labour is constructed as agreeing with a change in legislation, for example, in an interview in $D N$ (Littorin, 24 May 2017):

Ylva Johansson underlined that it isn't the government's place to interfere directly in a conflict.

“As minister of labour, I am, however, responsible for the legislations. I think we have a need to strengthen the laws in order for the successful Swedish model to function", says Johansson.

A change in legislation is shaped here as a condition to protect the interests of the nation and the Swedish model. An unexpected result is the representation of social democratic voices as being sceptical about workers using the conflict weapon, as implicitly expressed in the quotation of Johansson above, and voiced in the editorial of the social democratic $A B$ (Persson, 11 June 2018), as in the example below:

Take the negotiations of 2017 as an example. The national mediation office notes that nearly 500 agreements were signed. Only in 15 cases were state mediators needed, and not one single negotiation about a national agreement ended with a strike or lockout.

The lack of conflict is highlighted as a positive side of the agreement model, although the editorial also criticises an employee organisation that is claimed to have forced external mediation in some instances. These standpoints coming from social democratic voices serve to legitimise the role of LO-affiliated unions as the negotiators with the industry, something that is at the heart of the Swedish model, and something that is challenged by the Dockworker's Union's struggle. Against the seeming agreement between social democratic voices and business representatives, stressing the urgency to protect the interests of the nation, the Swedish model, and the public good, the actions and standpoints of the Dockworkers Union come across as hard to understand, sometimes as unreasonable actions disrupting the social order. This implies that attempts to protect working-class interests through conflict become something irresponsible and are framed as actions opposing the best interests of the nation - that is, they are constructed as the problem, which indicates a kind of class compromise where one-sided capitulations from the working class are expected (see Wright, 2000). 
In conclusion, this corporate framing about the port conflict turns class conflict into a battle where the nation's interests and the public good are at stake, and where protecting working-class interests through conflict becomes synonymous with disrupting vital societal functions. This naturalises capitalist class interests as common sense and serves to further legitimise neoliberal hegemony.

\section{The absorption of class critique}

The hegemonic workings of the media do not normally imply the complete omission of deviant or critical perspectives, but rather the absorption of these into the hegemonic framework, which in turn neutralises these positions (Allan, 1999; Gitlin, 2003). In the analysed material, the corporate viewpoints that guide much of the representation of the port conflict are complemented by constructions that in one way or another point to antagonistic interests between employers and workers. These constructions, however, are mainly portrayed as the subjective opinions of specific social actors, primarily by being set forth in opinion materials or by being attributed in news articles to a specific actor. We argue that this leads to the creation of a view where the existence of class struggle and antagonistic class interests - especially in relation to employers - are a subjective opinion rather than a central mechanism within capitalism. This, in turn, serves to foster the naturalisation of a corporate worldview, as observed in the previous section.

On one level, critique can be seen in quotations from and opinion materials by representatives from the Dockworker's Union, which centre their arguments around the need to sign a collective agreement and the dockworkers' democratic rights. When cited in news articles, these representatives comment or justify specific measures in the conflict. For example, a union representative states that "it is of course sad that they [businesses] suffer in this way", while also stressing the need to defend their union members (Littorin, DN, 18 August 2017). Moreover, in debate articles, the Dockworkers' Union argues for labour peace and good working conditions, and in one instance, defends their conflict measures by pointing to the employers' organisation and claiming, "It is you who threaten the Swedish model" (Berg, AB, 5 March 2019).

On another level, there are examples from opinion pieces where class struggle - in the form of a discursive emphasis on antagonistic interests between capitalists and workers - is constructed more directly. This discourse is embedded in a proworker critique against neoliberalism, the corporate class's attempts to increase their power vis-à-vis the workers, and the traditional workers' movement's compliance with this. Such discourse can, mainly, be found in the cultural pages of $A B$, which traditionally have been the site of leftist cultural and political critique. In an opinion column titled "The loot runs the city" (Nyberg, AB, 15 July 2017), focusing on the privatisation and financialisation of public services and work-related conflicts in relation to this, author Mikael Nyberg calls the corporate competition involved in these financialised services a "blackmail system", a term which serves to delegitimise these market-oriented practices from a workers' perspective. Furthermore, he goes on to argue that at the end of the day, it is more work for lower salaries that makes profit-making possible for a company that offers lower rates than its competitors. This framing points to the exploitation of workers, and a presupposition 
in Nyberg's argument is that the corporate class and the workers have antagonistic interests. This presupposition is also revealed in his framing of the port conflict in the last paragraphs of the article:

[...] and in Gothenburg social democrats and bourgeois politicians have, by common accord, put the port in the hands of Danish Maersk, a major group that has resolved to decrease the number of permanent employees to a fifth and paralysed great portions of the terminal tasks in its strive to crush the Dockworkers' Union.

The government answers with a review of new restrictions to the right to strike.

We should be thankful that garbage men, dockworkers, and others are trying to clean up the mess. It is time to help out. (Nyberg, AB, 15 July 2017)

This framing positions the interests of Maersk as antagonistic to the dockworkers' interests, which leads to a struggle between them. Similarly, in another cultural piece for $A B$, Nyberg (3 February 2019) states, "The port conflict is a stage in the long-lasting campaign to restrict the possibilities for workers and officials to defend themselves against the current retraction of everything that the workers' movement has fought for", presupposing a struggle between different class interests. Moreover, in an opinion piece in the cultural pages of $A B$ (Henriksson, 30 October 2017), which argues against a change in the strike law, a metalworker frames the proposed law as being "tilted towards protecting the interests of the corporations vis-à-vis the employees' and the public's interest of transparency and debate". Corporations are also here framed as having interests opposite those of employees, but also those of the public. Furthermore, in a cultural column in $D N$, criticising the LO attitude towards the port strike and the restrictions to the right to strike, sociologist Roland Paulsen (5 March 2018) explicitly makes reference to "class struggle" when arguing that so-called yellow unions, in contrast to other unions, objected to class struggle and the red colour of socialism. In an ironic manner, he then ends the article by saying that he does not understand why LO maintains the red colour, meaning that they should consider themselves a yellow union since nowadays they also object to class struggle. In this way, the ironic comment serves to delegitimise LO and accentuate the relevance of class struggle.

Moreover, a debate article written by three local-level LO representatives and signed by over 100 people makes references to the "incentives" of corporations to sign bargaining agreements (Bäckman et al., SvD, 31 January 2019). According to the authors, the proposed restrictions on the right to strike - which is what they argue against in the article - would take away corporations' incentives to sign bargaining agreements with the biggest unions. In this argument lies a presupposition that pairs incentives with conflict, which in turn reveals a view of antagonistic interests and struggle between workers and their employers.

Examples of this kind of discourse are rare in news articles, although there are a couple of examples from $D N$ where corporate interests become an object constructed. A piece titled "Researchers warn about restricted strike rights" (Nandorf, DN, 19 January 2018) frames the proposed restriction to the right to strike as a potential problem, because it could lead to wage dumping. This framing is attributed to voices within LO and a researcher in economics. Furthermore, the same article refers to a central LO representative who is said to want the port employer to put more pressure on the Dock- 
workers' Union and force them to sign a second-level agreement. He is also quoted as saying that the reason the employer does not do this is to create conditions for a change to the law. A couple of days later, a news article in $D N$ (Nandorf, 21 January 2018) quotes the vice CEO of the Confederation of Swedish Enterprises, who, when questioned about the risks of salary dumping with the proposed law, says that the claim is wrong. In this sense, the argument that class interests are a driving force is framed as one that can be either supported or rejected.

\section{Conclusions}

With the aim of examining how class as a category of conflict and struggle is understood and shaped discursively in mainstream media today, this study has examined the Swedish news media's coverage and (re)presentation of various opinions related to the recent port conflict in Sweden. Our analysis reveals two ways in which class relations are recontextualised in a post-political context. The first discursive pattern shows market interpretations as the legitimised point of departure in the ways in which the conflict is constructed, which obscures the class nature of the conflict. Central to this perspective is the nationalist-oriented discourse that equates corporate interests with what is best for the nation, a view also found in other studies (Cotal San Martin, 2019; Kumar, 2007 Salter \& Weltman, 2011). Central here is also the question of genre. By placing much of the news material in the economy section, as done by $D N$ and $S v D$, the port conflict is framed through a market-centred perspective where class relations are naturalised. This pro-market approach locks workers into an impossible equation because their resistance to corporate interests is then recontextualised as harmful for the well-being of business and the nation. This construction implies that the unequal power relationship between capital and labour, with the former having material advantages, is also reinforced by an ideological advantage where the media, by different editorial choices, manages to obscure and also naturalise class relations.

In contrast to the corporate approach guiding much of the coverage, explicit critique of class and exploitation, when it appears at all, is mainly reduced to opinion materials. The genre categorisation of the critique is significant also here because a framework emphasising class antagonism is made into an opinion rather than being a framework to structure news around. In this sense, class antagonism falls outside what newsrooms perceive as a legitimate controversy (Hallin, 1989) to frame news about the port conflict around. By opinionising class, critique against class relations is marginalised and absorbed by the hegemonic framework (see Allan, 1998; Gitlin, 2003).

The media discourse about the port conflict ought to be perceived as an indication of how the question of class is treated in the Swedish public sphere, and how it is ideologically limited. One must bear in mind that the scant explicit debate on class in the analysed material is not only because of the dominance of bourgeois voices, for whom uneven class relations are "business as usual", or the acceptance of a bourgeois ideology in newsrooms. The scant explicit debate about class is to a certain degree also explained by the lack of explicit critique of class relations among labour movement representatives. This is most evident in the ways in which social democratic politicians and labour movement representatives defend restrictions on the right to strike. This illuminates the ideological shift that has taken place in the Swedish political mainstream after the 
establishment of neoliberalism. Such a political climate, we argue, serves to limit the debate on class in the media and reinforces a post-political condition.

The seeming lack of interest in class among the labour movement is a high-risk project. In a time when neo-fascism is on the rise in Europe, and when members of the working class are migrating from the left to the far right, it becomes a kind of political suicide not to make class a central signifier in the political project of the left. By legitimising corporate interests and making them national interests, the left and the labour movement are blurring the ideological differences between them and the right, making it easier for working-class people, who are severely affected by neoliberalism, to embrace the far right, and making it less difficult for far-right parties to gain momentum.

\section{Note}

1. All excerpts are translated from Swedish by the authors.

\section{References}

Abalo, E. (2017). News for global sustainability? On the problems with reification and othering when reporting on social inequality. In P. Berglez, U. Olausson, \& M. Ots (Eds.), What is sustainable journalism? Integrating the environmental, social, and economic challenges of journalism (pp. 135-150). New York: Peter Lang. https://doi.org/10.3726/b11462

Allan, S. (1998). News from NoWhere: Televisual news discourse and the construction of hegemony. In A. Bell, \& P. Garrett (Eds.), Approaches to media discourse (pp.105-141). Oxford: Blackwell.

Allan, S. (1999). News culture. Buckingham: Open University Press.

Allvin, M., \& Sverke, M. (2000). Do new generations imply the end of solidarity? Swedish unionism in the era of individualization. Economic and Industrial Democracy, 21, 71-95. https://doi. org/10.1177/0143831X00211004

Bengtsson, M. (2008). Individen stämplar in: Arbetet, facket och lönen i sociologisk belysning [The individual punches in: Work, the union, and salary in sociological illumination] [Doctoral dissertation, Gothenburg University, Sweden]. http://hdl.handle.net/2077/17280

Bengtsson, S. (2019, June 18). Klart: Riksdagen säger ja till förändrad strejkrätt. [Done: The Parliament says yes to changed right to strike]. Arbetsmarknadsnytt. https:/www.arbetsmarknadsnytt.se/allmanna_nyheter/klart-riksdagen-sager-ja-till-forandrad-strejkratt_739948.html

Bennet, J. (2013). Chav-spotting in Britain: The representation of social class as private choice. Social Semiotics, 23(1), 146-162. https://doi.org/10.1080/10350330.2012.708158

Berg, M. (2019, March 5). Det är ni som hotar svenska modellen. [It is you who threaten the Swedish model]. Aftonbladet, 6.

Bäckman, D., Källefors, D., \& Crossler, R. (2019, January 31). Fel med förbud mot stridsåtgärder [Wrong to prohibit conflict measures]. Svenska Dagbladet, 6.

Carvalho, A. (2008). Media(ted) discourse and society: Rethinking the framework of critical discourse analysis. Journalism Studies, 9(2), 161-177. https://doi.org/10.1080/14616700701848162

Cederblad, J. (2017, May 19). Hamnkonflikten hot mot exportjättarna [The port conflict a threat to the export giants]. Svenska Dagbladet (SvD Näringsliv), 13.

Cotal San Martin, V. (2019). The mediated representation of working conditions in the Global South: Discourse, ideology and responsibility. Örebro, Sweden: Örebro University. http://oru.diva-portal.org/smash/ record.jsf?pid=diva2\%3A1324104\&dswid=-126

Dahl, M., \& Ärlund, J. (2018, January 31). Hamnarbetarförbundet äventyrar svenska modellen [The Dockworkers' Union jeopardises the Swedish model]. Dagens Nyheter, 5.

Davis, A. (2010). Politics, journalism and the new media: Virtual iron cages in the new culture of capitalism. In N. Fenton (Ed.), New media, old news: Journalism and democracy in the digital age (pp. 121-137). London: Sage. http://dx.doi.org/10.4135/9781446280010

DN (Dagens Nyheter). (2019, March 4). Storstrejk i hamnarna oroar näringslivet. [Big strike in ports worries the business world]. Dagens Nyheter, 18.

Eriksson, G. (2015). Ridicule as strategy for the recontextualization of the working class: A multimodal analysis of class-making on Swedish reality television. Critical Discourse Studies, 12(1), 20-38. https:// doi.org/10.1080/17405904.2014.962067

Fairclough, N. (1993). Discourse and social change. Cambridge: Polity Press. 
Freedman, D. (2010). The political economy of the 'new' news environment. In N. Fenton (Ed.), New media, old news: Journalism and democracy in the digital age (pp. 35-50). London: Sage. http://dx.doi. org/10.4135/9781446280010

Furåker, B. (2005). Sociological perspectives on labor markets. Basingstoke: Palgrave Macmillan.

Gitlin, T. (2003). The whole world is watching: Mass media in the making \& unmaking of the New Left. [New ed.] Berkeley: University of California Press.

Glasgow University Media Group. (1976). Bad news. London: Routledge/Kegan Paul.

Glasgow University Media Group. (1980). More bad news. London: Routledge/Kegan Paul.

Gramsci, A. (1971). Selections from the prison notebooks. London: Lawrence and Wishart.

Grönlund, A. (2004). Flexibilitetens gränser: Förändring och friktion i arbetsliv och familj [The limits of flexibility: Change and friction in working life and family]. Umeå, Sweden: Boréa Bokförlag.

Hall, S., Critcher, C., Jefferson, T., Clarke, J., \& Roberts, B. (1978). Policing the crisis: Mugging, the state, and law and order. London: Macmillan.

Hallin, D. C. (1989). The uncensored war: The media and Vietnam. Berkeley, California: University of California Press.

Hamnarbetarförbundet. (2019, February 27). Konflikt för att få till det kollektivavtal som varit förbundets mål sen start [Conflict to obtain the collective agreement that has been the association's goal since the start]. http://hamn.nu/article/2620/Konflikt-for-att-fa-till-det-kollektivavtal-som-varit-forbundets-malsen-start.html

Hart, C. (2017). Metaphor and intertextuality in media framings of the (1984-1985) British miners' strike: A multimodal analysis. Discourse \& Communication, 11(1), 3-30. https://doi.org/10.1177/1750481316683291

Harvey, D. (2010). The enigma of capital and the crises of capitalism. London: Profile Books.

Henriksson, L. (2017, October 30). Lagen som tystar arbetsplatserna [The law that silences the workplaces]. Aftonbladet, 5.

Herman, E. S., \& Chomsky, N. (2002). Manufacturing consent: The political economy of the mass media. New York: Pantheon Books.

Herman, E. S., \& McChesney R. W. (1997). The global media: The new missionaries of corporate capitalism. London: Cassell.

Jacobsson, D. (2018). Business elite competition or a common concern? Journalistic representations of industrial crises in Sweden. Journalism Studies, 19(1), 105-125. https://doi.org/10.1080/146167 0X.2016.1164615

Jacobsson, D., \& Ekström, M. (2016). Dismantling discourses: Compassion, coping and consumption in journalistic representations of the working class. Critical Discourse Studies, 13(4), 379-396. https:// doi.org/https://doi.org/10.1080/17405904.2015.1122644

Jakobsson, P., \& Stiernstedt, F. (2018a). Voice, silence and social class in television. European Journal of Communication, 33(5), 522-539. https://doi.org/https://doi.org/10.1177/0267323118784819

Jakobsson, P., \& Stiernstedt, F. (2018b). Naturalizing social class as moral category on Swedish mainstream television. Nordicom Review, 39(1), 81-94. https://doi.org/10.2478/nor-2018-0003

Kjellberg, A. (2011). The decline in Swedish union density since 2007. Nordic Journal of Working Life Studies, 1(1), 67-93. https://doi.org/https://doi.org/10.19154/njwls.v1i1.2336

Kumar, D. (2007). Outside of the box: Corporate media, globalization and the UPS strike. Chicago: University of Illinois Press.

Lawler, S. (2005). Disgusted subjects: The making of middle-class identities. Sociological Review, 53(3), 429-446. https://doi.org/https://doi.org/10.1111/j.1467-954X.2005.00560.x

Lindberg, I., \& Neergard, A. (2013). Bortom horisonten: Fackets vägval i globaliseringens tid [Beyond the horizon: The Unions' choice of path in times of globalisation]. Stockholm: Premiss Förlag.

Littorin, J. (2017, August 18). Hamnstriden slår hårt mot landets företag [The port conflict strikes hard against the country's businesses]. Dagens Nyheter, 20.

Littorin, J. (2017, May 24). S utmanar LO - öppnar för att begränsa konflikträtten [S challenges LO - opens up for a restriction of the conflict right]. Dagens Nyheter, 29.

Lugo-Ocando, J. (2015). Blaming the victim: How global journalism fails those in poverty. London: Pluto Press.

Lyle, S. (2008). (Mis)recognition and the middle class/bourgeois gaze: A study of wife swap. Critical Discourse Studies, 5(4), 319-330. https://doi.org/10.1080/17405900802405239

Machin, D., \& Mayr, A. (2012). How to do critical discourse analysis: A multimodal introduction. London: Sage.

Martin, C. (2007). Writing off workers: The decline of the US and Canadian labor beats. In C. McKercher, \& V. Mosco (Eds.), Knowledge workers in the information society (pp. 19-36). Lanham, Maryland: Lexington.

Marx, K. (1996). Capital, vol.1, New York: Lawrence \& Wishart.

Mouffe, C. (2005). On the political. London: Routledge. 
Nandorf, T. (2018, January 19). Forskare varnar för inskränkt strejkrätt [Researchers warn about restricted strike rights]. Dagens Nyheter, 17.

Nandorf, T. (2018, January 21). "Hamnarbetarförbundet missbrukar konfliktvapnet" ["The Dockworkers Union abuses the conflict weapon"]. Dagens Nyheter, 24.

Nerone, J. (2009). The death (and rebirth?) of working-class journalism. Journalism, 10(3), 353-355. https:// doi.org/10.1177/1464884909102596

Nyberg, M. (2017, July 15). Stålarna styr stan [The loot runs the city]. Aftonbladet, 4-5.

Nyberg, M. (2019, February 3). Planen: tysta facket [The plan: to silence the union]. Aftonbladet, 4-5.

OECD. (2017). OECD Economic Surveys: Sweden 2017. Paris: OECD Publishing. https://doi.org/10.1787/ eco_surveys-swe-2017-en

Paulsen, R. (2018, March 5). LO ser inte längre rött och sviker alla som sliter ont [LO does not longer see red and fails all who drudges]. Dagens Nyheter, 6.

Persson, I. (2018, June 11). Facken måste hålla samman [The unions must stick together]. Aftonbladet, 2.

Persson, M. (2017, January 27). Hamnstrejken hotar jobben [The port strike threatens the jobs]. Svenska Dagbladet, 2.

Rehmann, J. (2013). Theories of ideology - The powers of alienation and subjection. Chicago: Haymarket Books.

Salter, L., \& Weltman, D. (2011). Class, nationalism and news: The BBC's reporting of Hugo Chavez and the Bolivarian Revolution. International Journal of Media \& Cultural Politics, 7(3), 253-273. https:// doi.org/10.1386/macp.7.3.253_1

Savage, M., Bagnall, G., \& Longhurst, B. (2001). Ordinary, ambivalent and defensive: Class identities in the Northwest of England. Sociology, 35(4), 875-889. https://doi.org/10.1177\%2F0038038501035004005

Skeggs, B. (2004). Class, self, culture. London: Routledge.

Skeggs, B., \& Wood, H. (2011). Introduction: Real class. In H. Wood, \& B. Skeggs (Eds.), Reality television and class (pp. 1-29). London: Palgrave Macmillan.

Stiernstedt, F., \& Jakobsson, P. (2019). Defusing the male working class: Populist politics and reality television. European Journal of Cultural Studies, 22(5-6), 545-562. https://doi.org/10.1177/1367549418786423

SvD (Svenska Dagbladet). (2019, March 5). Totalstrejk får näringslivet att hålla andan [Total strike makes the business world hold its breath]. Svenska Dagbladet (SvD Näringsliv), 1.

Therborn, G. (2018). Kapitalet, överheten och alla vi andra: Klassamhället $i$ Sverige - det rådande och det kommande [Capital, the powers, and the rest of us: Class society in Sweden - the current and the future] Lund, Sweden: Arkiv förlag.

Tuchman, G. (1978). Making news: A study in the construction of reality. New York: Free Press.

Wright, E. O. (2000). Class counts: Comparative studies in class analysis. Cambridge: Cambridge University Press. https://doi.org/10.1017/CBO9780511488917

Wright, E. O. (2005). Foundations of a neo-Marxist class analysis. In E. O. Wright (Ed.), Approaches to class analysis (pp. 4-30). Cambridge: Cambridge University Press. https://doi.org/10.1017/ CBO9780511488900

Wodak, R., \& Meyer, M. (2009). Critical discourse analysis: History, agenda, theory and methodology. In R. Wodak, \& M. Meyer (Eds.) Methods of critical discourse analysis (pp-1-33). London: Sage. http:// dx.doi.org/10.4135/9780857028020

(C) 2021 Nordicom and respective authors. This is an Open Access work licensed under the terms of the Creative Commons Attribution-NonCommercial-NoDerivatives 4.0 International Public licence (CC BY-NC-ND 4.0). To view a copy of the licence, visit https://creativecommons.org/ licenses/by-nc-nd/4.0/ 